FINANSIA: Jurnal Akuntansi dan Perbankan Syariah P-ISSN: 2621-4636; E-ISSN: 2621-4644

\title{
STRATEGIC CHARITY IMPLEMENTATION IN INDONESIA'S RURAL ISLAMIC FINANCIAL INSTITUTION
}

\author{
Devi AyuKurniati \\ IAIN Salatiga \\ Devia4290@gmail.com \\ Agung Guritno \\ IAIN Salatiga \\ agung.guritno@iainsalatiga.ac.id
}

Accepted: October 2019 Revised: November 2019 Published: November 2019

\begin{abstract}
Strategic Charity, as the more specific implementation of Corporate Social Responsibility (CSR), is now gained its popularity among the company in Indonesia, including the Islamic Financial Institution. This study was conducted to determine the implementation of strategic charity done by BMT Al-Hikmah, Ungaran, Central Java. The method used was qualitative descriptive, and data collection was done using interviews and observations. The study revealed that the source of funds of the strategic charity comes from zakat, infaq, alms, and fines fund. The implementation itself is in the form of giving donations to schools, providing scholarships to disadvantaged communities around the BMT, distributing groceries to the poor, and several charity activities.
\end{abstract}

Keywords: Strategic Charity, Corporate Social Responsibility (CSR), BMT. 


\begin{abstract}
Abstrak
"Strategic Charity", sebagai implementasi yang lebih spesifik dari Tanggung Jawab Sosial Perusahaan (CSR), kini semakin populer di kalangan perusahaan di Indonesia termasuk Lembaga Keuangan Syariah. Penelitian ini dilakukan untuk mengetahui implementasi strategic charity yang dilakukan oleh BMT Al-Hikmah, Ungaran, Jawa Tengah. Metode yang digunakan adalah deskriptif kualitatif, dengan pengumpulan data dilakukan dengan wawancara dan observasi. Studi ini mengungkapkan bahwa sumber dana strategic charity berasaldari dana zakat, infaq, sedekah, dan denda. Implementasinya sendiri berbentuk pemberian donasi ke sekolah, pemberian beasiswa bagi masyarakat sekitar yang kurang mampu, pemberian bahan pokok kepa dawarga kurang mampu dan beberapa kegiatan amallainnya.
\end{abstract}

Kata kunci: Strategic Charity, Tanggung Jawab Sosial Perusahaan, BMT.

\title{
A. Introduction
}

Many scholars agreed that Corporate Social Responsibility (CSR) emerged for the first time during the 1950s or 1960s and came from the west ${ }^{1}$. CSR is the commitment of the business community to continue to act ethically, operate legally, and contribute to economic improvement, together with improving the quality of the economy and the quality of the local community as well ${ }^{2}$. Isa Wahyudi and Busyra Azheri proposed that CSR is a concept in which a company or business entity decides voluntarily to contribute to society and the environment $^{3}$. Asyraf Wajdi Dusukiviewed that in general, CSR is

${ }^{1}$ Wan Noor Hazlina Wan JusohandUzaimah Ibrahim, “Corporate Social Responsibility of Islamic Banks in Malaysia: Arising Issues, Islamic Economics Studies, Vol. 25 No. Special Issue, 2017, Page 156.See also Anisa RamadhiniTrianaputri, DodikSiswantoro, and Miranti Kartika Dewi, CSR in Islamic Financial Institution: A Literature Review,TIFBR: Tazkia Islamic Finance and Business Review, Vol. 11 No. 2, 2017, Page 108. Mohammad Yazis Ali Basah and Mazlynda Md Yusuf, Islamic Bank and Corporate Social Responsibility (CSR), European Journal of Business and Management, Vol. 5 No. 11, Page 195, 2013.AsyrafWajdiDusuki, Corporate Social Responsibilityof Islamic Banks in Malaysia: A Synthesis of Islamic and Stakeholders' Perspective, Doctoral Thesis, (England: Loughborough University, 2005).

2 Yusuf Wibisono, MembedahKonsepEAplikasi CSR (Corporate Social Responsibility). (Gresik: Fascho Publishing, 2007)

${ }^{3}$ Isa Wahyudi and BusyraAzheri, Corporate Social Responsibility: Prinsip, 
taken to denote corporate activities, beyond profit-making, which include protecting the environment, caring for employees, being ethical in trading, and getting involved in the local community ${ }^{4}$. Corporations and institutions do CSR by giving a portion of the company's profit to charity ${ }^{5}$. This means that CSR is an act of social responsibility or contribution made by the company to the surrounding environment so that the company could develop and the relationship between the company and the surrounding is maintained and harmonious.

Further, Asyraf Wajdi Dusuki proposed four areas covered by CSR's practices; those are: (1) the environmental dimension, (2) the human resource dimension, (3) the philanthropic dimension, and (4) the human right dimension. The detail of the areas covered by the CSR practices shown on the table below ${ }^{6}$ :

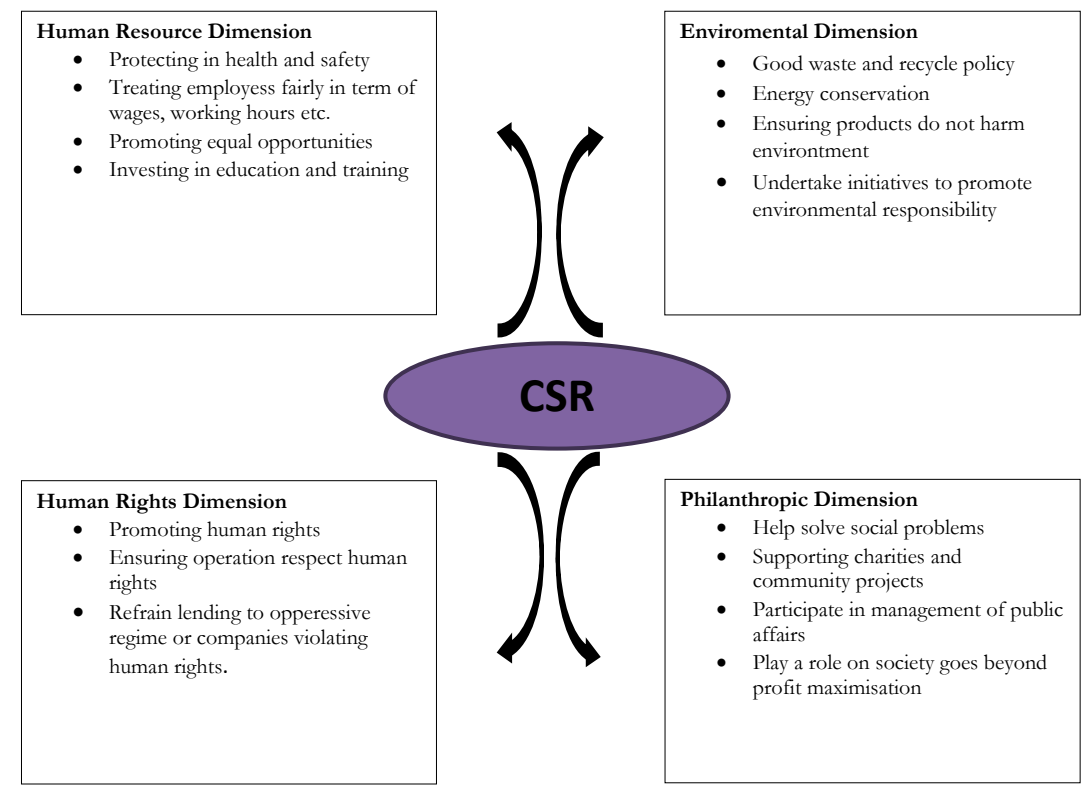

Picture 1. CSR Practice

Pengaturan, dan Implementasi. (Malang: In-Trans Publishing, 2008)

${ }^{4}$ AsyrafWajdiDusuki, What Does Islam Say about Corporate Social Responsibility?.Review of Islamic Economics, Vol. 12 No. 1, 2008, 5-28.

${ }^{5}$ Yusuf Sani Abubakar, (2016). Corporate Social Responsibility of Islamic Financial Institution: A Look from the Maqasid Al-Shariah (Purpose of Shariah) Approach. Business and Economics Journal, Vol. 7 No. 4, 2016, 2-4.

${ }^{6}$ Dusuki, Corporate Social Responsibility... 
In general, charity defined as an organization that raises moneyto help people in need and also an act of kindness andunderstanding towards others ${ }^{7}$. Charity in Islam is associated with sincere devotion to God and is a means to increased spiritual reward, and it also causes significant spiritual and socio-economic changes ${ }^{8}$. Muslim charities need to pool their efforts together to make the financial sector willing to offer better investment options, and this could be of benefit to the wider community. ${ }^{9}$

The term "strategic charity" mentioned by Hassan and Latiff ${ }^{10}$. The term derived from the word "strategic philanthropy" which refers to the practice of the corporate or company contributing funds to charitable while simultaneously benefiting the firm's financial bottom line and enhancing business political legitimacy ${ }^{11}$. Further, Hassan and Latiff elaborated strategic charity as a combination of pure philanthropy and business sponsorship with giving programs that directly or indirectly linked to business objectives.

Baitul MaalwaTamwil (BMT) is a financial institution that operates based on sharia principles and serves to improve the economy of the community and help the community in developing its business. BMT is a microfinance institution that operates on the principle of profit-sharing, fostering the development of micro business in order to raise degrees and dignity and defend the interests of the poor, grown on the initiative and initial capital of local community leaders based on safety economic system, peace, and

${ }^{7}$ Salwa Amirah Awang, et al, "The Concept of Charity in Islam: An Analysis on the Verses of the Qur' an and Hadith", Journal of Usuluddin, Vol. 45 No. 1, 2017, 142.

${ }^{8}$ BenaoudaBensaid, et al, "Ethico-Spiritual Dimensions of Charity: An Islamic Perspective", Middle-East Journal of Scientific Research, Vol. 13 No. 2, 2013, 171-182.

${ }^{9}$ Haroun Atallah, "Charities and Islamic Finance", www.gifr.net (Global Islamic Finance Report 2012).

10 Abul Hassan and Hjh Salma Binti Abdul Latiff, "Corporate Social Responsibility of Islamic Financial Institutions and Businesses Optimizing Charity Value", Humanomics, Vol. 25 No. 3, 2009, 177-177.

11 Thomas A. Hemphill, "Corporate Governance, Strategic Philanthropy, and Public Policy". Business Horizons, Vol. 42 No. (3), 1999, 57-62. 
prosperity ${ }^{12}$. Another similar opinion comes from Ahmad Sumiyanto in which BMT is a microfinance institution whose activities are following sharia principles and an institution that empowers people in the financial sector ${ }^{13}$.

BMT, as a part of the Islamic Financial Institution (IFI), is representativeof organizations of individuals who: 1). Invest their money as shareholders or investment account holders; 2). Have cooperative, partnership or borrowing relations with the IFI; 3). Are employed by the IFI; 4). Have other explicit contractual relations with the IFI; and 5). Have an implicit social contract with the IFI aspart of the larger community (Ummah) ${ }^{14}$ There is no accurate data about the total of BMT in Indonesia. According to KNKS (National Sharia Finance Committee), in 2019, there are at least 4.500 BMT across Indonesia (knks.go.id). This number is in doubt since there is no official statement about the exact amount from the authority. However, this indicates that BMT is needed and has a particular market in society.

This study will focus on the implementation of strategic charity activity held by BMT Al-Hikmah, Ungaran, Central Java. As elaborated before, this study will explore further about the process from the very beginning until the end. The method comprises: collecting the funds, selecting the proposal, and channeling the funds to the society.

\section{B. Method}

This research is descriptive qualitative. Qualitative is a research method used in a natural settingwhere the researcher as the main factor, the data collection using triangulation, and the result of the research emphasis on the meaning rather than generalizations ${ }^{15}$.

${ }^{12}$ Sumar'in, Konsep Kelembagaan Bank Syariah (Yogyakarta: Grahallmu,

${ }^{13}$ Ahmad Sumiyanto, BMT MenujuKoperasi Modern: Panduan UntukPemilik, Pengelola, dan Pemerhati, Baitul MaalWaTamwilDalam Format Koperasi (Yogyakarta: ISES Publishing, 2008)

${ }^{14}$ Sayd Farook, "On Corporate Social Responsibility of Islamic Financial Institutions, Islamic Economics Studies, Vol. 15 No. 1, 2007, 34

${ }^{15}$ Sugiyono, MemahamiPenelitianKualitatif (Bandung: CV. Alfabeta, 2009) 
In this research, the object is BMT Al-Hikmah, Ungaran, Central Java. There are two kinds of data provided, the primary data which obtained from the interview with the manager of BMT Al-Hikmah Ungaran,documentations, and also from the observations while the secondary data collected from other sources such as operational guidance book, etc.

\section{Result and Discussion}

As elaborated earlier, there are some steps in processing the strategic charity at BMT Al-Hikmah, Ungaran, namely: collecting the funds, selecting the proposal, and channeling the funds to the society ${ }^{16}$. These procedures seem short, but actually, it needs hard work and good teamwork to make it successful.

The initial step conducted by BMT Al-Hikmah, Ungaran is collecting the funds. The funds raised through some sources; (1). Zakat (zakatukasb al-amalwa al-mihan al-hurrah), which comes from the employees' earning each month. Each employee will set aside $2,5 \%$ of their income every month for zakat; (2).Infaq and Alms, these two sources are coming from the member (customer) of BMT. The member (customer) of BMT may donate their money as the social fund to BMT anytime regardless of the amount, and then later, BMT will organize it and channel it to the society; (3). Fines (penalty), this kind of fund taken from the member (customer) who borrows the money from BMT (the debtor) but late in paying the installment in a particular month. This penalty actually meant as a way to discipline the member of BMT in fulfilling their obligation every month. The funds from the fines are not considered as the income for the BMT; (4). CSR or social funds, BMT will set aside 2,5\% from their dividend as the fund for CSR or social funds.

The second step is BMT will analyze and select the proposal from the society asking for the social fund. The person in charge will scrutinize every need and making a list of priorities. The selected

${ }^{16}$ Muhari, General Manager, Interview, Ungaran, Maret 2019 
ones will get financial assistance from the BMT. The last step is the implementation or disbursement of the funds.

There are many kinds of activities to implement the strategic charity at BMT Al-Hikmah. The first is in the educational field. BMT Al-Hikmah gives donations to MTs Al-Falah in Bergas, Wujil, Kabupaten Semarang. BMT Al-Hikmah also offers scholarships to low-income families nearby so that their children able to keep pursuing their education.

The second, BMT Al-Hikmah gives it's attention to the employees and the members (customers). Anytime undesirable things happened to the employees or the members such as sick, hit by misfortune, or death, the BMT will give the donations. The third, the BMT supported the activities related to the faith of surrounding. Many times religious activities held by the community around the BMT's office. These activities are as precious occasions for BMT to get close to the society and also doing preaching at the same time.

The fourth, BMT distributes groceries, money, and gifts for the poor and also for the mosque's administrators nearby on the special occasion such as in Idulfitri moment. The fifth, BMT AlHikmah provides a car for social activities for the members and the community surrounding as part of community service. The members and the community may borrow the car anytime if they need, especially in urgent times related to humanity. The last, BMT Al-Hikmah, also gives donations to the victims of natural disasters across Indonesia. Usually, the contributions are hand over to other organizations that specialize in handling the problem.

The strategic charity carried out by BMT Al-Hikmah brings benefits both to the society around and BMT Al-Hikmah. The strategic charity makes the economic and social welfare of the surrounding community increased. This condition able to make a better quality of society itself. For BMT Al-Hikmah, the strategic charity brings benefits in some ways such as; as a means of promotion so that the surrounding community knows more about what Islamic financial institutions are; attract public interest to become a member of BMT AlHikmah, improving relations with stakeholders so they can develop 
their business better; and reducing the risk of BMT's business such as losses, tight competition, etc.

The charity activities seem very useful because the number of members of BMT is increasing from time to time. One of the factors that responsible for the increase is the name of BMT itself, which is getting more popular in society because of the charity activity. This makes an impact on the rise in the number of customers, deposits funds, financing, profits, and assets owned by BMT.

BMT Al-Hikmah is not a pure charity organization. As a financial institution, business and profits become the main goals of the company. However, BMT Al-Hikmah still wants to make a positive impact and social assistance to people who need it. This in line with the commitment of BMT itself. Those commitments are; 1). BMT is not only responsible for Islamic values institutionally but also Islamic values in the community where BMT located; 2). BMT concerns not only toward customers' economic aspect but also other aspects of customers' social community; 3). Improving BMT's professionalism over time by helping financial difficulties faced by the community.

\section{Conclusion}

The source of funds for the strategic charity of BMT AlHikmah Ungaran comes from zakat, infaq, alms, and fines collected from the customers who late in fulfilling their obligation each month. The strategic charity implemented in the field of education, social activities, etc. The strategic charity brings benefits to BMT and the society around. The strategic charity becomes a means to promote the BMT and its banking product, while the society's economic and social welfare is improving. 


\section{REFERENCES}

Books

Ahmad Sumiyanto, BMT Menuju Koperasi Modern: Panduan UntukPemilik, Pengelola, dan Pemerhati, Baitul Maal Wa Tamwil Dalam Format Koperasi. (Yogyakarta: ISES Publishing, 2008). Isa Wahyudi dan BusyraAzheri, Corporate Social Responsibility: Prinsip, Pengaturan, dan Implementasi. (Malang: In-Trans Publishing, 2008).

Sugiyono, MemahamiPenelitianKualitatif, (Bandung: CV. Alfabeta, 2009).

Sumar'in, KonsepKelembagaan Bank Syariah, (Yogyakarta: Grahallmu, 2012).

Yusuf Wibisono, MembedahKonsepEAplikasi CSR (Corporate Social Responsibility), (Gresik: Fascho Publishing, 2007).

\section{Scientific Articles}

Abul Hassan and Hjh Salma Binti Abdul Latiff. "Corporate Social Responsibility of Islamic Financial Institutions and Businesses Optimizing Charity Value." Humanomics, Vol. 25 No. 3, 2009.

Anisa RamadhiniTrianaputri, DodikSiswantoro, and Miranti Kartika Dewi, “CSR in Islamic Financial Institution: A Literature Review."Tazkia Islamic Finance and Business Review, Vol. 11 No. 2, 2017.

AsyrafWajdiDusuki, "What Does Islam Say about Corporate Social Responsibility?" Review of Islamic Economics, Vol. 12 No. 1, 2008.

BenaoudaBensaid, FadilaGrine, MohdRoslanMohd Nor, and Mohd Yakub ZulkifliMohdYusoff, "Ethico-Spiritual Dimensions of Charity: An Islamic Perspective." Middle-East Journal of Scientific Research, Vol. 13 No. 2, 2013. 
Mohammad Yazis Ali Basah andMazlynda Md Yusuf, "Islamic Bank and Corporate Social Responsibility (CSR)."European Journal of Business and Management, Vol. 5 No. 11,2013.

Salwa Amirah Awang, Fidlizan Muhammad, Joni TamkinBorhan, and Mohammad Taqiuddin Mohamad, "The Concept of Charity in Islam: An Analysis on the Verses of the Qur'an and Hadith." Journal of Usuluddin, Vol. 45 No. 1, 2017.

Sayd Farook, "On Corporate Social Responsibility of Islamic Financial Institutions, Islamic Economics Studies, Vol. 15 No. 1, 2007.

Thomas A. Hemphill, "Corporate Governance, Strategic Philanthropy, and Public Policy." Business Horizons, Vol. 42 No. 3, 1999.

Wan Noor Hazlina Wan Jusoh and Uzaimah Ibrahim, "Corporate Social Responsibility of Islamic Banks in Malaysia: Arising Issues."Islamic Economic Studies, Vol. 25 No. Special Issues, 2017.

Yusuf Sani Abubakar, "Corporate Social Responsibility of Islamic Financial Institution: A Look from the Maqasid Al-Shariah (Purpose of Shariah) Approach."Business and Economics Journal, Vol. 7No. 4, 2016.

\section{Thesis/Dissertation}

AsyrafWajdiDusuki, Corporate Social Responsibilityof Islamic Banks in Malaysia: A Synthesis of Islamic and Stakeholders' Perspective, Doctoral Thesis, (England: Loughborough University, 2005).

\section{Online Resources and Interview}

Muhari, BMT AL-Hikmah General Manager, Interview, Ungaran, March 2019

Haroun Atallah, "Charities and Islamic Finance", www.gifr.net (Global Islamic Finance Report 2012).

https:/ / knks.go.id/isuutama/8/sharing-platform-keuangan-mikrosyariah-berbasis-baitul-maal-wat-tamwil-bmt 